Al-Uqud: Journal of Islamic Economics E-ISSN 2548-3544, P-ISSN 2549-0850 Accredited No. 28/E/KPT/2019
Volume 4 Issue 1, January 2020

DOI:10.26740/al-uqud.v4n1.p146-161

Page 146-161

\title{
Revisiting Zakat Distribution on Income Inequality and Welfare: The Malaysia Experience
}

\author{
Patmawati Ibrahim ${ }^{1 *}$, Mazliana Muridan' ${ }^{2}$ Maimunah $\mathrm{Ali}^{3}$, Amirul Iman Mohd \\ Jazid $^{4}$
}

1,2,3,4Faculty of Technology Management and Business, Universiti Tun Hussein Onn Malaysia, 86400 Parit Raja, Batu Pahat, Johor, Malaysia

\begin{abstract}
This paper attempts to analyze the effects of zakat distribution on income inequality and welfare aspects of the poor Muslim society in Malaysia. The population of the study is the poor and hardcore poor of the zakat recipients in Selangor. Exploring the cross sectional micro level data of nine districts in Selangor, Malaysia, this study adopted Lorenz curve and Gini coefficient to represent positive measures of income inequality. However, these measures do not take into account the welfare effects of the distribution to the society. Hence, Atkinson index is adopted to represent the normative measures of inequality that takes into account the welfare effects of the zakat distribution to society. Results of the Gini coefficient and Lorenz curve have proven effectiveness of zakat distribution in reducing income inequality of the society. Whilst the theory of zakat says that zakat distribution will improve income inequality and welfare of the society, findings of the normative measures in this research show otherwise. Therefore, this study is extended with zakat distribution simulation model based on had kifayah. Results from the distribution simulation model proved the ability of zakat in narrowing down income inequality, reducing income loss and hence increasing the welfare of the society.
\end{abstract}

Keywords: Zakat distribution; Income inequality; Welfare economics; Gini coefficient and Lorenz curve; Atkinson index; Malaysia

Paper type: Research paper

*Corresponding author: patmawati@uthm.edu.my

Received: July 02, 2019; Accepted: January 15, 2020; Published: January 20, 2020

Cite this document: Ibrahim, P., Muridan, M., Ali, M., \& Mohd Jazid, A. I. (2020). Revisiting Zakat Distribution on Income Inequality and Welfare: The Malaysia Experience. Al-Uqud: Journal of Islamic Economics, 4(1), 146-161. https://doi.org/10.26740/aluqud.v4n1.p146-161

Copyright (C) 2020, Al-Uqud: Journal of Islamic Economics

http://journal.unesa.ac.id/index.php/jie 


\begin{abstract}
Abstrak: Kajian ini bertujuan untuk menganalisis kesan pengagihan zakat ke atas ketakseimbangan agihan pendapatan di kalangan umat Islam golongan fakir dan miskin di Malaysia. Populasi kajian ini adalah penerima bantuan zakat dari asnaf fakir dan miskin. Menggunakan data peringkat mikro, kajian ini menggunakan keluk Lorenz dan Koefisien Gini untuk mewakili kaedah mengukur ketidakseimbangan positif. Namun, kaedah ini tidak mengambil kira tentang aspek kebajikan masyarakat. Oleh itu, kajian ini mengadoptasi indeks Atkinson untuk mewakili langkah-langkah normatif yang mengambil kira kesan kebajikan dari pengagihan zakat kepada masyarakat. Walaupun teori zakat menyatakan bahawa pengagihan zakat akan mengurangkan ketidaksamaan agihan pendapatan dan meningkatkan kebajikan masyarakat, hasil kajian ini menunjukkan sebaliknya. Oleh itu, kajian ini diteruskan dengan menghasilkan simulasi model agihan zakat berdasarkan had kifayah. Hasil simulasi agihan zakat ini membuktikan keupayaan zakat untuk mengurangkan jurang ketakseimbangan agihan pendapatan, dan meningkatkan kebajikan rakyat.
\end{abstract}

Kata kunci: Agihan zakat; Ketakseimbangan agihan pendapatan; Ekonomi kebajikan; Koefisien gini dan Keluk Lorenz; Indeks atkinson; Malaysia

\title{
INTRODUCTION
}

Income inequality is an extreme disparity of income distributions with a high concentration of income usually in the hands of a small percentage of a population. When income inequality occurs, there is a large gap between the wealth of one population segment compared to another (Kopp, 2019). There are wide variety of types of economic inequality, most notably measured using the distribution of income (the amount of money people are paid), and the distribution of wealth (the amount of wealth people own). Besides economic inequality between countries or states, there are also important types of economic inequality between different groups of people (Ventura, 2018).

Islam is for equity in the distribution of income (Ridlwan, 2017; Fikriyah \& Ridlwan, 2018; Fikriyah, Ridlwan, \& Suryaningsih, 2019). Additional policy measures are suggested to even out whatever the degree of inequality that have not been taken care of by the functional distribution of income. This is done through the provisions of transfer payment, which refers to transfer of income and wealth from the relatively well-off people to the worse-off population. In Islam, distribution through transfers may be broadly divided into three categories; namely compulsory transfers, recommended transfers, and distribution through inheritance. Zakat is a kind of compulsory transfer. In brief, it acts as a transfer mechanism that enables the haves to help the needy and poor in society, hence paving the way towards an efficient, fair and equitable distribution of resources. It is also considered a kind of welfare assistance. According to theory, zakat distribution will reduce inequality in income distribution, and welfare loss of the society. In other words, zakat distribution is hypothesized to have positive contribution in improving the income distribution and the welfare of the society. Practically it has been proven by previous researches on this topic.

Mannan, Imtiazi, Niaz, \& Deria (1989) observed the role of zakat towards improvement in the standard of living, level of income and hence the alleviation of poverty and the reduction of income and wealth disparities through multiplying 
effects of zakat. Zakat-financed projects in fields such as education, medical care, social welfare etc., will raise the productivity of the poor by meeting the requirements of the basic necessities of life. The income of the poor is expected to increase, resulting thus from their higher productivity. However, in a critique of Malaysia's zakat system, a research has found that zakat was collected from the poor and paid out to the poor (Wahab et.al., 1995).

One influential work on zakat and inequality is the work of Jehle, (1994). Employing AKS index of inequality, Jehle examined the impact of zakat on income inequality in Pakistan. The result showed that zakat did reduce income inequality in Pakistan. His study suggested that both intra-province and inter-province components of overall inequality decline, though the amount of change is small. According to Hassan \& Ahmed (2000), zakat proceeds must be sufficient to make an effective redistribution of wealth and income for the benefit of the poor. This means that, in principle zakat must be given as a direct transfer payment to the poor. The purpose of zakah is to guarantee the fulfillment of the basic needs of the poor and realize fair social welfare in society (Al Haq \& Norazlina, 2017). Zakat prevents social welfare loss and reduce inequality among communities (Ibrahim, 2015).

In the socio-economic framework, among the major objectives of zakat is to reduce income inequality. Empirical study by Kusuma \& Sukmana, (2010), had identified three stages of distribution schemes known as; pre-distribution stage, post-distribution stage and redistribution in the Islamic views. Their findings identified two important issues; first, equitable distribution to the poor and needy could result in sound opportunities in the economy; and second, that there were positive changes in growth and inequalities. A study conducted by Beik \& Arsyianti (2016) found the fact that zakah has alleviated poverty and improved social welfare. However, a study by Khasandy \& Badrudin (2019), indicated that in Indonesia, zakat did not influence economic growth and welfare of the society. The study analyzed the influence of zakat on economic growth and welfare society by using 3 (three) indicators which are HDI, Percentage of Poor People, and Gini Index. It found negative values of HDI and Gini index for Indonesia.

Ayuniyyah, Pramanik, Saad, \& Ariffin (2018) investigate zakat distribution programs in poverty alleviation and income inequality reduction among groups in urban and rural areas have proven to be a success. The study was featuring a case study of 1,309 zakat beneficiaries managed by the National Zakat Board of Indonesia (BAZNAS) in different cities and regencies. The analytical tools used in this study were a modified Centre of Islamic Business and Economic Studies (CIBEST) model, the deciles method and the Gini coefficient. The study suggested that in general, the present zakat distribution programs can alleviate poverty and reduce income inequality among the observed zakat beneficiaries.

Ibrahim, (2006) studied the economic role of zakat in reducing income inequality and poverty in Malaysia. She applied Gini coefficient and Atkinson index of inequality in her study to answer the question of whether post-zakat assistance income distribution is more equally distributed than pre-zakat assistance income distribution. Further from that, the study attempted to measure the degree of welfare loss of the society due to inequality in income distribution. This is 
important as to be able to say that the welfare loss of the society has reduced along with the distribution of zakat in the society. Her study had shown that based on positive measures of Lorenz curve and Gini coefficient, zakat distribution has improved the income distribution. However, taken the welfare aspect into account by normative measure, the Atkinson index did not support the theory. Instead, the findings revealed that the then zakat distribution had worsened the inequality in income distribution, increased income loss, and thus reduced the welfare of the society. Her study extended with five simulation models to analyze the effects of different zakat distribution models on income inequality and welfare of the society. Both the five models had shown better results. However, the best simulation model was not properly highlighted. Hence, this paper will reproduce the result of the previous study, represent and highlight the result of the best simulation model. It is hope that the best model can be replicated for a better income distribution, less income loss and better social welfare of the society.

\section{RESEARCH METHODS}

The state of Selangor, one of the fourteen states in Malaysia was selected as a study area providing the primary source of data for this research. The state of Selangor comprises of both the rural and urban area which made a good representative of Malaysia. There are nine districts in Selangor, namely Gombak, Klang, Kuala Langat, Kuala Selangor, Petaling, Sabak Bernam, Sepang, Ulu Langat, and Ulu Selangor. The districts of Gombak, Klang, Petaling and Ulu Langat are grouped under urban area, whereas Kuala Selangor, Kuala Langat, Sabak Bernam, Sepang and Ulu Selangor are of rural area.

The population of this study was the zakat recipients in the state of Selangor from the hardcore poor and the poor (fuqara and masakin) categories. A method of stratified random sampling procedure was applied. A total number of 480 households out of 5862 total population were selected as samples representing the entire population. This figure was about 8 percent of the total population. The samples were selected from the list of zakat recipients from the hardcore poor and the poor categories (asnaffakir and miskin) provided by the Selangor Zakat Center (PZS). Household unit was taken as unit of observations in this study. Of each districts, only three areas were selected.

\section{Survey Modules}

A set of questionnaire was set up. There were five major parts of the questionnaire. The first part (Part A) was on the background and basic information of the head of households and their household's member.

The second part (Part B) was on the size and sources of monthly household's income. The third part (Part C) was on the monthly expenses of the households. The fourth part (Part D) was details on assistance received by the households from poverty eradication agencies. All types and forms of assistance were transformed into money value to get the total amount of assistance.

The last part (Part E) was on the evaluation of the respondents on the various types and forms of zakat assistance given to them and their future expectation. 


\section{Data Processing Program}

SPSS program was used to process the information from the questionnaires. The final data then extracted to estimate the income inequality models adopted in this study. Microsoft Excel did the calculation.

\section{Empirical Method}

This study was a type of inter-temporal analysis, investigating the effects of zakat distribution on income inequality and welfare of the society. There were two sets of data tested, one was before the amount of zakat distribution included in the household income, $f\left(y_{1}\right)$. Another set of data was after the amount of zakat distribution included in the household income $f\left(y_{2}\right)$. To see the effect of zakat distribution on income inequality and welfare loss of the society, the inequality measures were estimated on both data sets.

\section{Inequality Measures}

There are two classes of income inequality measures. The first class is positive measures, which makes no explicit use of any concept of social welfare, and the second is normative measures, which is based on an explicit formulation of social welfare and the loss incurred from unequal distribution.

One of the positive measures of income inequality is Gini coefficient. It is based on the comparison of cumulative proportions of the population against cumulative proportions of income they receive. Its value ranges from 0 (or $0 \%$ ) to 1 (or 100\%), with the former representing perfect equality (wealth distributed evenly) and the latter representing perfect inequality (wealth held in few hands). Today, the Gini coefficient is still one of the most widely used tool to chart the economic gap within a country's wealthiest and poorest citizens (Ventura, 2018). One way of viewing it is using the Lorenz curve.

The normative measures take into account the social welfare, are also known as the alternative measures. Atkinson (1970) applied 'The Social Welfare Function Approach' in his index of inequality. It presents the percentage of total income that a given society would have to forego in order to have more equal shares of income between its citizens. This measure depends on the degree of society aversion to inequality. Measures of inequality were used to analyse whether the distribution of income more equal than it was in the past? In this study, the main concern was to answer the question of whether the income distribution of 'post-zakat assistance' is better than the 'pre-zakat assistance'.

\section{Positive Measures: Lorenz Curve and Gini Coefficient}

Lorenz curve is the most common and the simplest way to analyze personal and households income distributions. It is a cumulative distribution plotting population share to the corresponding income share. In a perfectly equal distribution, the Lorenz curve would be a straight diagonal line from the point of zero population and income to that of total population and income. If income is not distributed equally, the Lorenz curve will be a convex curve lying below the diagonal line. 


\section{Gini Coefficient}

Value of the Gini Coefficient index of inequality lies between 0 (perfect equality) and 1 (perfect inequality). By calling $U$ the complement of $I$ in the right triangle $T$, we write ;

$$
G=\frac{I}{T}=\frac{T-U}{T}=1-\frac{U}{T}
$$

For the population group denoted as $a b$ in the figure, we write;

$$
\begin{aligned}
& U_{a b}=(b d)(a b)+\frac{1}{2}(c e)(a b)=(b d)(a b)+\frac{1}{2}(a c-b d)(a b) \\
& =\frac{1}{2}(a b)(b d+a c)
\end{aligned}
$$

In order to calculate an overall coefficient of inequality, one would have to sum the area under the curve $U$ for all the population groups. Since $T$ can be written as $1 / 2$, thus we can write;

$$
G=1-\sum(a b)(b d+a c)
$$

This study employed equation (3); $G=1-\sum(a b)(b d+a c)$ to derive Gini Coefficient. The population is divided into deciles groups, therefore, the value of $a b$ is $10 \%$, which is equal to 0.1 , whereas $b d$ and $a c$ are the amount of percentage of income received by the percentage of the population respectively. The value of $\mathrm{G}$ was in between 0 and $1(0 \leq G \leq 1) . \mathrm{G}=0$ indicates complete equality in the income distribution of the society, whereas $\mathrm{G}=1$ indicates complete inequality in the income distribution of the society.

The difference between with and without zakat distributions as measured by the Gini coefficient is termed as "reduction index" (Ismail Salleh and Rogayah Ngah, 1980). This index indicates of whether zakat has improved the income distribution among zakat recipients. If the value of the reduction index is positive, it means that zakat distribution has improved the income distributions, vice versa.

\section{Normative Measure: Atkinson Index of Inequality}

The two major objectives to be achieved in this study through Atkinson's index of inequality are; First, to quantify the differences in inequality between the two distributions so as to be able to say that the income distribution of the post-zakat distribution is more equally distributed than the income distribution of the pre-zakat distribution. Second, to measure the degree of welfare loss of the society due to inequality in the income distribution of the society in order to be able to say that the welfare loss of the society is reduced with the existence of zakat distribution in the society households' income.

The Atkinson index is based explicitly on the social welfare evaluation of income distribution. Let $y=\left(y_{1}, y_{2}, \ldots, y_{n}\right)$ denote an income distribution among 
$n$ individuals, where $y_{i} \geq 0$ is the income of individual $i(i=1, \ldots, n)$. Denote the mean income level by $\mu$, so that

$$
n \mu=\sum_{i=1}^{n} y_{i}
$$

Given a social welfare function, the Atkinson index is constructed by computing the equally distributed equivalent income, $Y_{E D E}$ of the distribution. This is defined as the level of income per head, which, if equally distributed, would give the same level of social welfare as the existing distribution, that is,

$$
U\left(Y_{E D E}\right) \int_{0}^{\bar{y}} f(y) d y=\int_{0}^{\bar{y}} U(y) f(y) d y
$$

The "equally distributed equivalent income, $\left(Y_{E D E}\right)$ " is yield by deflating the mean income of the poor, $m$ by $\left(1-G_{p}\right)$, corresponding to the rank order welfare function. (Anand, 1983).

Thus,

$$
Y_{E D E}=\frac{m}{\left(1-G_{p}\right)}
$$

where

$m:$ mean income of the poor, and

$G_{p}$ : Gini coefficient of the poor.

Atkinson's index is then defined as the difference between $\left(Y_{E D E}\right)$ and the mean income of the distribution, $\mu$ in proportionate terms, which is,

$$
I=1-\frac{Y_{E D E}}{\mu}
$$

or 1 minus the ratio of the equally distributed equivalent level of income to the mean of the actual distribution. The measure $I$ has the convenient property of lying between 0 (complete equality) and 1 (complete inequality). This measure has considerable intuitive appeal. Lower value of $I$ indicates more equal income distribution.

Since the Atkinson index is based explicitly on the social welfare evaluation of income distribution, the value of $I$ also denotes the degree of welfare loss of the society due to unequal income distribution. For example, if the value of $I=0.3$, then we can say that there are 30 percent welfare loss in the society due to unequal income distribution. It allows us to say that if incomes were equally distributed, then we should need only 70 percent of the present national income to achieve the same level of social welfare. 

Jazid: Revisiting Zakat Distribution on Income Inequality and Welfare: The Malaysia Experience

\section{RESULTS AND DISCUSSION}

\section{Positive Measures : Lorenz Curve and Gini Coefficient}

This study analyzes the size distribution of income of the households and the total income they received. All households are arranged by ascending household total income, and then divided into successive deciles according to ascending income levels. Each deciles represents $10 \%$ of the population. The first decile represents the bottom $10 \%$ of the population on the income scale, and so on. Finally, the last decile represent the top $10 \%$ of the population. This determined the proportion of the total income received by each income group.

Table 1. Selangor: Size Distribution of Household Income with and Without the Zakat Distribution

\begin{tabular}{ccccc}
\hline & \multicolumn{4}{c}{ Percentage Share in Total Income } \\
\cline { 2 - 5 } $\begin{array}{c}\text { Percentage of } \\
\text { Population }\end{array}$ & Without Zakat Distribution & With Zakat Distribution \\
\cline { 2 - 5 } & Deciles & $\begin{array}{c}\text { Cumulative } \\
\text { Deciles }\end{array}$ & Deciles & $\begin{array}{c}\text { Cumulative } \\
\text { Deciles }\end{array}$ \\
\hline 10 & 0.4 & 0.40 & 0.93 & 0.93 \\
20 & 1.31 & 1.71 & 1.95 & 2.88 \\
30 & 2.49 & 4.21 & 3.19 & 6.07 \\
40 & 4.05 & 8.26 & 4.54 & 10.62 \\
50 & 5.71 & 13.97 & 6.41 & 17.02 \\
60 & 7.58 & 21.55 & 8.49 & 25.52 \\
70 & 10.26 & 31.81 & 10.56 & 36.35 \\
80 & 13.65 & 45.46 & 13.82 & 50.18 \\
90 & 18.57 & 64.03 & 17.84 & 68.01 \\
100 & 35.97 & 100 & 31.99 & 100 \\
\hline
\end{tabular}

Table 1 shows size distribution of household income with and without the zakat distribution. Before the zakat distribution, the bottom $10 \%$ of the population enjoying only $0.4 \%$ of the total income as compared to the top $10 \%$ which enjoyed $35.97 \%$ of the total income. Alternatively, the bottom $40 \%$ of the population received only $8.26 \%$ of the total income, while the top $20 \%$ of the population enjoy $54 \%$ of the total income. After receiving the zakat distribution, the bottom $10 \%$ of the population receiving almost $10 \%$ of the total income whereas the top $10 \%$ of the population income portion reduced to $32 \%$.

\section{Lorenz Curve}

The improvement in income distribution after the zakat distribution is presented in the form of Lorenz curve by plotting population share to the corresponding income share, all in percentages. Figure 1 presents Lorenz curve of the state of Selangor before and after the zakat distribution included in the household income. 


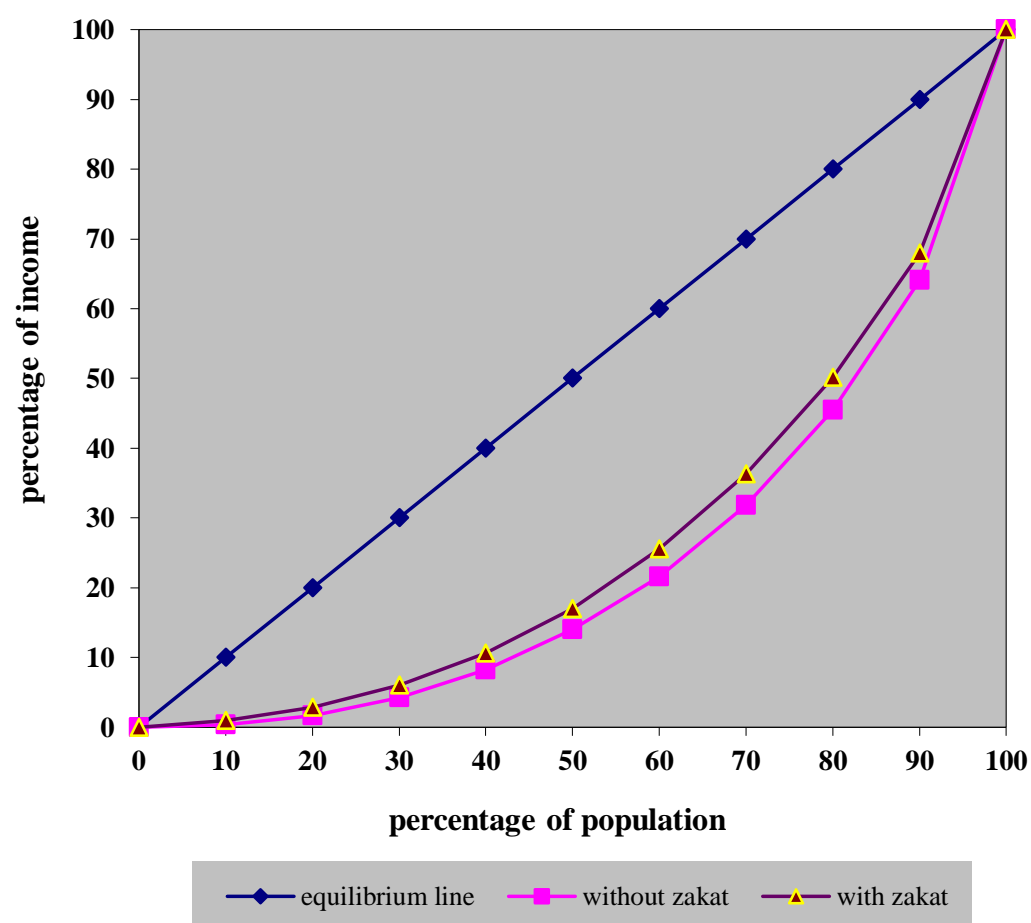

Figure 1. Selangor: monthly household income with and without zakat distribution

In the figure, the percentages of income recipient are plotted in horizontal axis, and percentage of income on vertical axis. Figure 1 shows Lorenz curves for the households' income distribution of Selangor, with and without the zakat distribution. It is noted from the curves that with zakat distribution, the Lorenz curve is closer to the perfect equality line (egalitarian line) as compared to the prezakat Lorenz curve. This means that with the zakat distribution, there is an improvement in the income distribution of the society towards more equal distribution.

\section{Gini Coefficient}

The values of Gini Coefficient proved the results of the Lorenz curves. Table 3 presents the value of Gini coefficient with and without the distribution of zakat to the households' income, and the value of reduction index.

Table 2. Selangor: Gini Coefficient Value with and Without Zakat Distribution (by districts)

\begin{tabular}{lccc}
\hline \multicolumn{1}{c}{ Districts } & $\begin{array}{c}\text { Without Zakat } \\
\text { Distribution }\end{array}$ & $\begin{array}{c}\text { With Zakat } \\
\text { Distribution }\end{array}$ & Reduction Index \\
\hline Selangor overall & 0.52 & 0.47 & 0.05 \\
Urban area & & & \\
Gombak & 0.59 & 0.56 & 0.03 \\
Hulu Langat & 0.51 & 0.45 & 0.06 \\
Klang & 0.43 & 0.38 & 0.05 \\
Petaling & 0.51 & 0.46 & 0.05 \\
\hline
\end{tabular}



Jazid: Revisiting Zakat Distribution on Income Inequality and Welfare: The Malaysia Experience

\begin{tabular}{lccc}
\hline \multicolumn{1}{c}{ Districts } & $\begin{array}{c}\text { Without Zakat } \\
\text { Distribution }\end{array}$ & $\begin{array}{c}\text { With Zakat } \\
\text { Distribution }\end{array}$ & Reduction Index \\
\hline Rural area & & & \\
Hulu Selangor & 0.42 & 0.38 & 0.04 \\
Kuala Langat & 0.55 & 0.48 & 0.07 \\
Kuala Selangor & 0.50 & 0.46 & 0.04 \\
Sepang & 0.54 & 0.48 & 0.06 \\
Sabak Bernam & 0.43 & 0.45 & -0.02 \\
\hline
\end{tabular}

From the table, income inequality in Selangor has improved quiet significantly with the help of zakat distribution. Without the zakat distribution, income inequality slightly high with Gini coefficient value equal to 0.52 in Selangor overall and exceeding 0.5 in six districts and 0.4 in the other three districts of Klang, Hulu selangor and Sabak Bernam. The worst income distribution prior to the zakat distribution is in Gombak ( $\mathrm{G}=0.59)$, and the least is in Hulu Selangor $(\mathrm{G}=0.42)$.

With zakat distribution, income distribution becomes better when the Gini coefficient in all district declining to less than 0.5, (excepting Gombak, which reduced to 0.56 ). In other words, based on Gini coefficient index, zakat distribution has improved the income distribution in Selangor towards more equal distribution.

The values of reduction index show positive values indicating positive contribution of the zakat distribution to the income distribution, with the exception of Sabak Bernam. Analyzing the data, we found that the negative value of reduction index is due to the reduction in inequality at the low income level is less than the increase in inequality income distribution at the high- income level.

Normative Measure: Atkinson Index

Table 3 shows the results of Atkinson index of inequality analysis ( $I$ ).

Table 3. Index of Inequality Analysis: With and Without Zakat Distribution

\begin{tabular}{lccccccccccc}
\hline \multirow{1}{*}{ Districts } & \multicolumn{4}{c}{ Without Zakat } & \multicolumn{1}{c}{ With Zakat } \\
\cline { 2 - 11 } & $\boldsymbol{m}$ & $\mu$ & $\mathbf{G}$ & $\begin{array}{c}\mathbf{Y}_{\mathbf{E D}} \\
\mathbf{E}\end{array}$ & $\mathbf{I}$ & $\boldsymbol{m}$ & $\mu$ & $\mathbf{G}_{\mathbf{P}}$ & $\begin{array}{c}\mathbf{Y}_{\mathbf{E D}} \\
\mathbf{E}\end{array}$ & $\mathbf{I}$ \\
\hline $\begin{array}{l}\text { Selangor } \\
\text { overall }\end{array}$ & 209 & 574 & 0.41 & 356 & 0.38 & 241 & 778 & 0.34 & 365 & 0.53 \\
$\begin{array}{l}\text { Urban area } \\
\text { Gombak }\end{array}$ & 164 & 827 & 0.45 & 299 & 0.63 & 201 & 887 & 0.42 & 346 & 0.61 \\
Hulu Langat & 199 & 514 & 0.42 & 341 & 0.34 & 259 & 639 & 0.29 & 369 & 0.42 \\
Klang & 255 & 864 & 0.37 & 405 & 0.53 & 312 & 980 & 0.28 & 436 & 0.55 \\
Petaling & 191 & 839 & 0.44 & 344 & 0.59 & 226 & 970 & 0.29 & 321 & 0.67 \\
Rural area & & & & & & & & & & \\
Hulu Selangor & 213 & 492 & 0.42 & 369 & 0.25 & 233 & 744 & 0.38 & 375 & 0.49 \\
Kuala Langat & 204 & 525 & 0.46 & 380 & 0.28 & 228 & 680 & 0.34 & 346 & 0.49 \\
\hline Kuala Selangor & 157 & 336 & 0.44 & 281 & 0.16 & 200 & 515 & 0.39 & 332 & 0.35 \\
\hline
\end{tabular}




\begin{tabular}{lccccccccccc}
\hline & \multicolumn{4}{c}{ Without Zakat } & \multicolumn{4}{c}{ With Zakat } \\
\cline { 2 - 12 } Districts & $\boldsymbol{m}$ & $\mu$ & $\mathbf{G}$ & $\begin{array}{c}\mathbf{Y}_{\mathbf{E D}} \\
\text { Sepang }\end{array}$ & $\mathbf{I}$ & $\boldsymbol{m}$ & $\mu$ & $\mathbf{G P}_{\mathbf{P}}$ & $\begin{array}{c}\mathbf{Y}_{\mathbf{E D}} \\
\mathbf{E}\end{array}$ & $\mathbf{I}$ \\
\hline Sabak Bernam & 206 & 577 & 0.38 & 331 & 0.43 & 251 & 740 & 0.24 & 330 & 0.55 \\
\hline
\end{tabular}

Note:

$\mathrm{Y}_{\mathrm{EDE}} \quad$ : Equally distributed equivalent income (RM)

$m$ : mean income of the poor (RM)

$\boldsymbol{\mu}$ : mean income of the population (RM)

I : Atkinson index of inequality

GP : Gini coefficient of the poor

From the table, both the mean income of the poor and the mean income of the population increased with zakat distribution. The value of Gini coefficient of the poor $\left(\mathrm{G}_{\mathrm{p}}\right)$ reduced with zakat distribution, which indicates improvement in the income distribution of the poor. The value of $\mathrm{Y}_{\mathrm{EDE}}$ is always lower than the value of $\mu$. This means that, if income is equally distributed in the society, smaller amount of income will give the same level of social welfare as the existing distribution.

Prior to the zakat distribution, the Atkinson index of inequality in Selangor overall, shows a value of 0.38 . The mean income of existing distribution is RM 574. If incomes were equally distributed, it would require only RM 356 per household to achieve the same level of social welfare. In other words, if income were equally distributed, it would require only $62 \%$ of the current income to get the same level of welfare of the current distribution. The $38 \%$ income "loss" equivalent to RM 274 is due to inequality in the distribution. ${ }^{1}$

After zakat distribution was included in the household income, both the value of $\boldsymbol{\mu} \boldsymbol{~ a n d} \mathrm{Y}_{\mathrm{EDE}}$ increased. Zakat distribution to the households' income has increased the mean income to RM 778. However, if incomes were equally distributed, the new distribution would require only RM 365, instead of RM 778 per household to achieve the same level of social welfare. The proportionate income "loss" has now increased to $53 \%$, which gives a value of 0.53 for $I$.

These figures inform us that whilst zakat distribution has increased the households' income, inequality in income distribution also increased at the same time, as indicated by the increasing value of the Atkinson index, I from 0.38 (38\%) prior to the zakat distribution to $0.53(53 \%)$ after the zakat distribution. The increase in income inequality has worsen the welfare loss. This situation is happened to all the districts of Selangor, excepting Gombak. Based on the Atkinson

\footnotetext{
${ }^{1}$ Mean income $=\mathrm{RM} 574$. Income loss due to inequality $=0.38$.

$\mathrm{Y}_{\mathrm{EDE}}=\mathrm{RM} 356 ;(356 / 574) \times 100=0.62$. Thus, $\mathrm{Y}_{\mathrm{EDE}}$ is equal to 62 percent of the mean income distribution. The amount of income loss $=0.38 \times R M$ 574=RM 218.

Income loss $(\mathrm{RM} 218)+\mathrm{Y}_{\mathrm{EDE}}(\mathrm{RM} 356)=$ mean income of the distribution (RM 574)
} 
index of inequality, income distribution is the worst in Gombak, both with and without zakat distribution. Analysis of the urban-rural income distribution reveals that income distribution in the rural area is better off than that of the urban area.

Hence, based on Atkinson index of inequality, which takes into account the welfare aspects of the society, the contribution of zakat distribution to the income distribution and welfare of the society in Selangor is negative. This is totally in contrast to the theoretical expectations of zakat, on which the zakat distribution would contribute positively to the welfare and income distribution of the society.

The results indicated that existing format of zakat distribution has led to the unexpected results. Therefore, this study was extended with a simulation of zakat distribution model in an attempt to find the best model/pattern of zakat distribution that would contribute positively in reducing income inequality and income loss, thus improve the welfare of the society.

\section{Simulation}

Four general assumptions were set up for the simulation:

1. Those whose income below the poverty line are considered poor, and below half of the poverty line are considered hardcore poor.

2. The vulnerable line income is equivalent to the amount of minimum wage rate. Households with monthly income is in between the PLI and minimum wage rate are considered vulnerable group of poverty.

3. The households with monthly income exceeding the minimum wage rate are considered non-poor.

Assumptions:

1. Zakat distribution to the poor and hardcore poor will be given based on had kifayah;

2. Zakat assistance to the vulnerable group will be given according to the needs; and

3. No distribution to the non-poor.

\section{Simulation Results}

Table 4 summarized the impact of zakat distribution on inequality measures by presenting the value of Gini coefficient and Atkinson index in the three situations, without the zakat distribution, with the zakat distribution, and under the simulation.

Table 4. Index of Inequality Analysis -

With and Without Zakat Distribution and the Simulation Results

\begin{tabular}{lcccccc}
\hline \multirow{2}{*}{ Districts } & \multicolumn{2}{c}{$\begin{array}{c}\text { Without } \\
\text { Zakat }\end{array}$} & \multicolumn{2}{c}{ With Zakat } & \multicolumn{2}{c}{ Simulation } \\
\cline { 2 - 7 } & $\mathbf{G P}_{\mathbf{P}}$ & $\mathbf{I}$ & $\mathbf{G}$ & $\mathbf{I}$ & $\mathbf{G}$ & I \\
\hline $\begin{array}{l}\text { Selangor overall } \\
\text { Urban area }\end{array}$ & 0.41 & 0.38 & 0.34 & 0.53 & 0.20 & 0.16 \\
Gombak & & & & & & \\
Hulu Langat & 0.45 & 0.63 & 0.42 & 0.61 & 0.24 & 0.29 \\
\hline
\end{tabular}




\begin{tabular}{lcccccc}
\hline \multirow{2}{*}{\multicolumn{1}{c}{ Districts }} & \multicolumn{2}{c}{$\begin{array}{c}\text { Without } \\
\text { Zakat }\end{array}$} & \multicolumn{2}{c}{ With Zakat } & \multicolumn{2}{c}{ Simulation } \\
\cline { 2 - 7 } & GP & I & GP & I & G & I \\
\hline Klang & 0.37 & 0.53 & 0.28 & 0.55 & 0.18 & 0.24 \\
Petaling & 0.44 & 0.59 & 0.29 & 0.67 & 0.13 & 0.10 \\
Rural area & & & & & & \\
Hulu Selangor & 0.42 & 0.25 & 0.38 & 0.49 & 0.18 & 0.01 \\
Kuala Langat & 0.46 & 0.28 & 0.34 & 0.49 & 0.23 & 0.14 \\
Kuala Selangor & 0.44 & 0.16 & 0.39 & 0.35 & 0.19 & 0.05 \\
Sepang & 0.38 & 0.43 & 0.24 & 0.55 & 0.24 & 0.18 \\
Sabak Bernam & 0.36 & 0.16 & 0.36 & 0.55 & 0.29 & 0.17 \\
\hline
\end{tabular}

Results of the simulation shown that income distribution measured by both the positive measure (Gini coefficient) and the normative measure (Atkinson index) are more equally distributed in Selangor overall as well as in both rural and urban areas. Another encouraging finding of this simulation is that the value of inequality in each district was less than 0.3. Specifically, it indicates that the income loss of the society due to inequality is less than 30 percent, with a maximum loss of 29 percent (urban area: Gombak) and the minimum income loss of only 1 percent (rural area: Hulu Selangor). The findings of this simulation reveal that the new pattern of zakat distribution is more effective in the rural area where the value of inequality in income distribution is less than 0.2. The simulation model achieved a maximum of 99 percent social welfare level, while the income losses due to inequality is only 1 percent in Hulu Selangor.

Table 5. Selangor: Income Inequality Reduction Index

\begin{tabular}{lcc}
\hline \multicolumn{1}{c}{ Districts } & Existing Model & $\begin{array}{c}\text { Simulation } \\
\text { Model }\end{array}$ \\
\hline $\begin{array}{l}\text { Selangor overall } \\
\text { Urban area }\end{array}$ & 0.05 & 0.32 \\
Gombak & & \\
Hulu Langat & 0.03 & 0.35 \\
Klang & 0.06 & 0.32 \\
Petaling & 0.05 & 0.25 \\
Rural area & 0.05 & 0.38 \\
Hulu Selangor & & \\
Kuala Langat & 0.04 & 0.24 \\
Kuala Selangor & 0.07 & 0.32 \\
Sepang & 0.04 & 0.31 \\
Sabak Bernam & 0.06 & 0.3 \\
& -0.02 & 0.14 \\
\hline
\end{tabular}

Table 5 is comparing the values of reduction index in existing zakat distribution model and the simulation model. The results show that the simulation model of zakat distribution has led to greater reduction in income gap. Thus, the simulation model of zakat distribution which is based on the use of had kifayah as the poverty line has proven the best impact on income inequality reduction. 
According to this model, zakat assistances for the two categories of fuqara and masakin should be distributed to the hardcore poor, the poor, and the vulnerable group only. The minimum amount of zakat distribution should be equivalent to the had kifayah gap.

\section{CONCLUSION}

This study has shown the ability of zakat as a transfer mechanism to reduce income inequality, minimizing income loss, and increases the welfare of the society. We would say that, following the simulation pattern of zakat distribution, each and every poor, hardcorepoor and the vulnerable groups of household in Selangor will get better income distribution, least income loss and higher welfare level. The most important is to implement the right pattern of zakat distribution as identified in this study.

\section{REFERENCES}

Ali, A. F. M., \& Aziz, M. R. A. (2014). Zakat poverty line index and gender poverty in Malaysia : Some issues and practices. International Journal of Business and Social Science, 5(10),286-293. Retrieved from http://ijbssnet.com/journals/Vol_5_No_10_September_2014/36.pdf

Ali, I., Azman, A., Singh, P., Singh, J., Drani, S., Hatta, Z. A \& Akhter, T. (2019). Zakat as an Alternative of Microcredit for Poverty Reduction in Bangladesh. The Journal of Development Practice, 5(Annual), 10-19. http://journals.dbuniversity.ac.in/ojs/index.php/jdp/article/view/739

Al Haq, M. A. \& Norazlina, A. W. (2017) Effective Zakat Distribution: Highlighting Few Issues and Gaps in Kedah, Malaysia. Al-Iqtishad: Journal of Islamic Economics, 9 (2). pp. 259-288. ISSN 2087-135X

Atkinson, A. B. (1970). On the measurement of inequality. Journal of Economic Theory, 2(3), 244-263. http://doi.org/10.1016/0022-0531(70)90039-6

Atkinson, A. B., \& Brandolini, A. (2015). Unveiling the ethics behind inequality measurement: Dalton's contribution to economics. Economic Journal, 125(583), 209-234. http://doi.org/10.1111/ecoj.12225

Ayuniyyah, Q., Pramanik, A. H., Saad, N. M., \& Ariffin, M. I. (2018). Zakat for Poverty Alleviation and Income Inequality Reduction. Journal of Islamic Monetary Economics and Finance, 4(1), 85-100. http://doi.org/10.21098/jimf.v4i1.767

Bakar, M. A., \& Ghani, A. A. (2011). Towards Achieving the Quality of Life in the Management of Zakat Distribution to the Rightful Recipients (The Poor and Needy). International Journal of Business and Social. https://doi.org/10.1787/459aa7f1-en

Beik, I. S., \& Arsyianti, L. D. (2016). Measuring Zakat Impact on Poverty and Welfare Using Cibest Model. Journal of Islamic Monetary Economics and Finance. 1. 141-160. https://doi.org/10.21098/jimf.v1i2.524

Fikriyah, K., Ridlwan, A. A. (2018) The Evaluation of Mustahiq EmpowermentBased Poverty Alleviation Program at Amil-Zakat Organizations. International Journal of Islamic Business and Economics (IJIBEC), 2 (1), 6573. https://doi.org/10.28918/ijibec.v2i1.1263 
Fikriyah, K., Ridlwan, A. A., \& Suryaningsih. (2019). International Journal of Civil Engineering and Technology 10 (02), 375-381

Hassan, M. K. \& Ahmed., M. (2000). "Poverty Alleviation and Zakat Funds : Substitutability of Zakat Funds in the Budget of the Government of Bangladesh", The Balance, Spring 2000.

Ibrahim, P. (2006). Economic Role of zakat in Reducing Poverty and income Inequality. Universiti Putra Malaysia. Retrieved from https://data.oecd.org/inequality/income-inequality.htm

Ibrahim, S. M. (2015). The Role of Zakat in Establishing Social Welfare and Economic Sustainability. International Journal of Management and Commerce Innovations, 3(1), 437-441. https://www.academia.edu/14694602/The_Role_of_Zakat_in_Establishing Social_Welfare_and_Economic_Sustainability

Jehle, G. A. (1994). Zakat and Inequality :Some Evidence From Pakistan. Review of Income and Wealth, 40(2). http://doi.org/10.1787/459aa7f1-en

Johari, F., Aziz, M. R. A., \& Ali, A. F. M. (2014). The role of zakat in reducing poverty and income inequality among new convert (muallaf) in Selangor, Malaysia. Online Journal of Research in Islamic Studies, 1(3), 43-56. https://doi.org/10.1787/459aa7f1-en

Kakwani, N. C. \& Podder, N. (1976). Efficient Estimation of the Lorenz Curve and Associated Inequality Measures From Grouped Observations. Econometrica, 44(1), 137-148. http://doi.org/10.1787/459aa7f1-en

Khasandy, E. A., \& Badrudin, R. (2019). The Influence of Zakat on Economic Growth and Welfare Society in Indonesia. Integrated Journal of Business and Economics, 3(1), 65. http://doi.org/10.33019/ijbe.v3i1.89

Kopp, C. (2019). What is Income Inequality. http://doi.org/10.1787/459aa7f1-en

Kusuma, D. B. W., \& Sukmana, R. (2010). "The power of zakah in poverty alleviation" Seventh International Conference - The Tawhidi Epistemology: Zakat and Waqf Economy, Bangi 2010. http://www.ukm.my/hadhari/wpcontent/uploads/2014/09/proceedings-seminar-waqf-tawhidi.pdf

Ventura, L. (2018). Wealth Distribution and Income Inequality by Country 2018. https://doi.org/10.1787/459aa7f1-en

Majlis Agama Islam Selangor Darul Ehsan. (1994). Fatwa Sistem Agihan Zakat Negeri Selangor Darul Ehsan. Selangor. Retrieved from https://data.oecd.org/inequality/income-inequality.htm

Mannan, M.A., Imtiazi I.A., Niaz M.A. \& Deria A.H. (1989). Management of Zakat in Modern Muslim Society, Jeddah: Islamic Research and Training Institute, IDB.

Newberry, D. (2018). A theorem on the measurement of income inequality. Journal of Economic Theory, (2), 264-266. http://doi.org/10.1787/459aa7f1-en

Nurjanah, F., Kusnendi, \& Juliana. (2019). The Impact of Economic Growth and Distribution of Zakat Funds on Poverty (Survey in the Third District of West Java Province Period 2011-2016). In The 2nd International Conference on Islamic Economics, Business, and Philanthropy (ICIEBP) Theme: "Sustainability and Socio Economic Growth" (Vol. 3, p. 55). KnE Social Sciences. http://doi.org/10.18502/kss.v3i13.4195 
Pyatt, G. (2018). On The Interpretation And Disaggregation of Gini Coefficients. The Economic Journal, 86(June). http://doi.org/10.1787/459aa7f1-en

Rohim, A. N. (2018). Maximizing Utility And Distributing Income Equitably: How does Zakah Impact Both of Them at Once? Islamic Economics Journal, 4(2), 155. http://doi.org/10.21111/iej.v4i2.2963

Ridlwan, A. A., (2017). The Determinant Factors of Motivation to Pay Zakat in Regional Amil Zakat Agency of East Java. KARSA: Journal of Social and Islamic Culture 25 (2), 334-345. http://doi.org/10.19105/karsa.v25i2.1398

Roslan, A. H. (2001). Income Inequality, Poverty And Development Policy In Malaysia. In Poverty and Sustainable Development. France. http://doi.org/10.1787/459aa7f1-en

Shorrocks, A. F. (2004). Inequality and Welfare Evaluation of Heterogenous Income Distributions. Journal of Economic Inequality, 2, 193-218. http://doi.org/10.1787/459aa7f1-en

Wahab, M. B. A., Al-Junaidi, S. A. H., Omar, M. A. Bin, Ghazali, A. Bin, Osman, J. Bin, \& Arif, M. (1995), "Institutional Framework of Zakah: Dimensions and Implications - Case Study of Malaysia”, Seminar Proceedings No. 23, Jeddah: IRTI-IDB 